\title{
RESEARCH PAPER \\ EFFECTS OF SHORELINE EROSION ON INFRASTRUCTURE DEVELOPMENT ALONG THE COASTAL BELT OF GHANA: CASE OF NKONTOMPO COMMUNITY
}

\author{
G. F. A. Olympio and S. Amos-Abanyie \\ Department of Architecture, KNUST, Kumasi \\ olympiogeorge@yahoo.com and sumwelamos@yahoo.com
}

\begin{abstract}
The coastal areas of Ghana are the locus of rapid urban and industrial growth, oil and gas development, industrial-scale fisheries, recreation and tourism destinations. However, lateral changes in the coastline position has seriously threatened the equilibrium of the coastal environment and affected the socio-economic life of local populations, threatened cultural heritage and hindered coastal tourism development. This paper assessed the extent of shoreline recession and its effects on buildings and infrastructure along Ghana's coastline through a study of the Nkontompo Community, a suburb of Sekondi in the Western Region of the country as a case. The study employed data spanning a period of 23 years, including Topographic sheets that were interpolated to establish the rate of recession of the shoreline. The extent of land lost in conjunction with the building density was used to establish the number of buildings lost. The study revealed that environmental conditions at Nkontompo have changed over the past three to four decades as a result of shoreline erosion. The coastline of the community has been receding at a rate of approximately 2 metres per annum. From the topographical sheet interpolations and analysis made by the authors, it was realized that approximately nine acres of the land, forming a third of the total built up area has been eroded leading to damage and subsequent loss of about 117 buildings to the sea. Recommendations have been made identifying adaptation techniques and strategies to manage the effects of this phenomenon along the coastal belt of Ghana.
\end{abstract}

Keywords: Coastal erosion, infrastructure development, Nkontompo, Ghana

\section{INTRODUCTION}

Infrastructure development is generally considered as an important determinant of economic development and a priority for public investment. The quality of infrastructure services directly determines the quality of life for a community and its productivity (Samli, 2010).
The coastal areas are the locus of rapid urban and industrial growth, oil and gas development, industrial-scale fisheries and tourism. There is a general trend of population increase in the coastal areas, with the coastal cities serving as principal growth nodes. Over $70 \%$ of the world's beaches are experiencing coastal ero- 
sion as a result of coastal retreat (Anthony, 2005). This presents a serious hazard to many coastal regions, where about $60 \%$ of the human population lives (Al-Tahil and Asim, 2004). The trend of erosion is expected to increase under the scenario of rising sea level as a result of climate change. It has been estimated that by 2025 the coastal zone from Accra to the Niger delta could be an unbroken chain of cities, with a total population of 50 million along $500 \mathrm{~km}$ of coastline (Hatziolos et al., 1996). According to the IPCC (2001) coastal erosion and the progressive flooding of coastal lowlands are likely to increase, largely as a consequence of the rise in sea level due to global warming.

The coastline of Ghana, over the years, like many others in the rest of the world has changed as a result of changes in the natural environment. Such changes according to Oteng Ababio et al (2011) have occurred over a wide range of temporal and spatial scales that reflect influences such as movement of the earth crust, and variations in sea level and climate. Ricketts (1986) asserts that coastal erosion, which is a natural geomorphic process, becomes a hazard when it poses or is perceived to pose a threat to life and property. In Ghana, the lateral changes in the coastline position has resulted in coastal erosion, which has destroyed the coastal environment, affected the socio-economic life of the local population, threatened cultural heritage and hindered coastal tourism development (Appeaning-Addo, 2009).

Furthermore, many of the most densely populated coastal areas are low-lying coastal plains susceptible to flooding (Boateng, 2006). The vulnerability of the shoreline of Ghana to erosion is further heightened by its zonal orientation and the fact that it is an open coast that enables swell waves to break obliquely to the shoreline, generating long shore currents that carry sediments along the shore (Armah, 1991).

Studies by Nail et al. (1993) identified twentyfour coastal erosion hot-spots in Ghana that need urgent attention. Erosion is a chronic issue along the Ghanaian coastline, where high erosion rates are affecting coastal infrastructure and valuable cultural resources. Erosion rates of as high as 1 metre/year have been measured near the country's capital city, Accra (OtengAbabio et al, 2011).

Parts of the East Coast of Ghana near Keta are one of the segments that have been worse affected, with coastal erosion persisting for over a century (NADMO, 2007; Cotsape and Hayes, 1997). The historic rate of erosion was about four metres per annum (Ly, 1980) before the construction of the Keta Sea defense structures.

In the western part of the Accra coast, 17 coastal inhabitants have lost their buildings to coastal erosion over a 26-year period (Campbell, 2006). A model simulation by Appeaning-Addo et al. (2008) under scenarios of climate change indicates that coastal erosion at Faana in Accra may be severe in the future and that the sandbar that separates the sea from the Sakumo wetlands will be breached between 2052 and 2082. For the coastal belt of Ghana as a whole, the impacts can negate many development prospects of the country, causing severe problems to its poor people living along the coast. A typical area that is also experiencing shoreline recession is Nkontompo, a suburb of Sekondi in the Western Region of Ghana.

The objectives of the study were to assess the extent of shoreline recession and how buildings and infrastructure have been affected along the coastline of Ghana with the Nkontompo Community as a case study. This is expected to lead to the recommendation of adaptation techniques and strategies to manage the effects of shoreline erosion along the coastal belt of Ghana.

\section{Profile of Ghana's shoreline}

Ghana has high concentrations of population and infrastructure along its coastal belt and within a $200 \mathrm{~m}$ radius from the shoreline. The coastal zone in Ghana represents only about $7 \%$ of the total land area of the country (Armah and 
Amlalo, 1998), but according to the 2000 population and housing census, it is home to about $25 \%$ of the nation's total population of 24 million (GSS, 2002).

Ghana has a coastline of $550 \mathrm{~km}$ along the Atlantic Ocean (Armah and Amlalo, 1998). Previous studies, including Ly (1980), have categorized the coastal belt of Ghana into three geomorphic units namely, the West Coast, Central Coast and East Coast. The coastal zone is generally described as low lying and below the $30 \mathrm{~m}$ contour above sea level, thus making it prone to erosion, the extent and degree of which depends on the geology and the location of the area concerned (EPA, 2000). The coastal areas of Ghana have dense and growing populations and developing commerce. This is where most of the industrial infrastructure is located, historically because of access to port facilities. The coastal towns and cities are likely to continue to be nodes of population growth for the foreseeable future, with opportunities over the longer term for people to improve their economic well-being. There are all types of settlements ranging from urban centres to small fishing villages. A wide range of economic activities takes place in the coastal belt of Ghana; fishing, salt winning industries, seaports, and oil and gas exploration. There are prominent archaeological and historical heritage sites (Anquandah, 1999). The coastal belt of Ghana offers scenic beauty with appeal for tourism. An international trunk road linking the West African countries runs along the coastline of Ghana.

Locally, coastal erosion along the shoreline of Ghana has been caused by coastal engineering, such as port development interrupting the longshore transport of protective beach sediment. Large-scale infrastructure development, including damming of the Volta River and the construction of deep-water harbours such as the Tema and Takoradi habours, and the Naval Base, has disrupted the natural movement of sediment along the beach and nearshore (the "littoral" zone) and the delivery of sediment to the coast. Such large-scale infrastructure development leads to the retention (by damming) of river-borne sediments that would have otherwise been discharged at the coast (WCD, 2000; Crossland et al, 2005).

Coastal management strategies in Ghana, have largely focused on the provision of hard protection at specific locations where risk levels to life and economic assets are high. Initially there were plans to protect all coastal settlements with populations greater than 10 persons per $\mathrm{km}^{2}$ (Table 1) and at risk with sea defence wall (EPA, 2000). Because of the high cost involved it was then limited to areas with acute erosion problems. Interventions along the coastline have not been carried out in a systematic fashion, and attempts at erosion mitigation has ranged from placement of rock revetments scattered at some segments of the coast line to large engineering projects such as the the sea defense wall at Keta along the Volta River delta in the south eastern part of Ghana (Boateng, 2006). Short of dismantling existing dams, there is little that can be done in mitigation other than installing expensive coastal defenses.

\section{THE STUDY AREA}

Nkontompo, a suburb of Sekondi, is one of the numerous settlements along the west end of the Central Coast in the Sekondi-Takoradi Metropolitan Area, one of the twenty-two (22) administrative districts of the Western Region.

Nkontompo occupies an elevated coastal plain with the lowest point being approximately 3.3 $\mathrm{m}$ above sea level and the highest being $31 \mathrm{~m}$ above sea level (TCPD, 1991). A sandy beach marks the shoreline of Nkontompo. According to the Community Elders the shoreline has been affected by severe erosion over the past four decades. The main drainage outlet is the Atlantic Ocean. The elders of the community further revealed that the current natural environmental condition is a deviation from that of the past four decades. While the shoreline has historically receded, erosion has become exacerbated by efforts to control the problem. Typical of 
42 Olympio and Amos-Abanyie

Table 1: Population Density by Coastal Districts of Ghana

\begin{tabular}{lll}
\hline District & & Population Density (persons/:km ${ }^{2}$ ) \\
West Coast & & \\
& Jomoro & 48.0 \\
Central Coast & Nzema East & 38.0 \\
& & \\
& Abura-Asebu-Kwamankese & 203.0 \\
& Accra & 3383.0 \\
& Ahanta East & 643.0 \\
& Ahanta West & 147.0 \\
& Awutu Efutu & 115.0 \\
& Cape Coast & 710.0 \\
& Ga & 138.0 \\
& Gomoa & 159.0 \\
& Komenda & 202.0 \\
Mfantsiman & 234.0 \\
East Coast & \\
& Adidome & 62.0 \\
& Akatsi & 92.0 \\
& Ga-Danbge East & 110.0 \\
& Ga-Danbge West & 44.0 \\
& Keta & 138.0 \\
& Denu & 66.0 \\
& Sogakokpe & 109.0 \\
Tema & 467.0 \\
\hline
\end{tabular}

(Source: GSS, 2000)

other areas in Ghana, in 1990 a revetment wall was put in place to protect coastal structures that are threatened by erosion at Nkontompo.

Land area especially in the south-western part, along the coastline has been lost to the sea. Along the coast, the beauty of the coconut plantations has been wiped out. Along the northern end of the community runs a major road connecting Sekondi to Takoradi, the capital of the Western Region, and a national railway line. The location of the road and the railway limits development and expansion of the community. The entire land of the community has limited vegetative cover. The situation is compounded by the reduction in the intensity as well as the irregular pattern of rainfall. There are agencies in the District with specific and related duties that seek to protect the environment from over exploitation and degradation. The SekondiTakoradi Metropolitan Assembly, which is the highest planning authority in the Metropolis, is expected to manage the environment. The Sekondi-Takoradi Metropolitan Assembly operates through various agencies at the regional and at the national levels. These institutions have had very little influence on the management of the local natural environment. They include the Town and Country Planning Department (TCPD), Survey Department and the Environmental Protection Agency (EPA). 
APPROACH TO DATA COLLECTION AND ANALYSIS

The study made use of both quantitative and qualitative data collected from both primary and secondary sources. The first part of the study was devoted to a careful review of available relevant literature on coastal erosion. The second part involved extensive use of interviews with three groups of people: (i) local residents of the study area; (ii) opinion leaders of the community; and (iii) key informants. Local residents interviewed were purposefully selected paying attention to residents of between 15 and 25 years of stay in the community who were expected to have witnessed the erosion trends in the community over the years. The researchers were able to locate only 14 of such local residents who were in a position to grant interview and were all interviewed. Opinion leaders interviewed were representatives of the Community Development Committee which is a sub-group of the Traditional Council and the assemblyman of the community. The interviews of the opinion leaders and local residents focused on their awareness of the effects of shoreline erosion, knowledge on the extent and levels of erosion, frequency, magnitude and their preparedness for erosion related extreme events. Interviews were held with key informants comprising experts and scientists working in the field of development and with knowledge on the research matter. Institutions where key informants were interviewed included the Building and Road Research Institute (BRRI), Environmental Protection Agency (EPA), Architectural and Engineering Services Limited (AESL), the Ministry of Water Resources, Works and Housing, the Departments of Civil Engineering and Architecture of the Kwame Nkrumah University of Science and Technology, Kumasi (KNUST). The subject of the interviews focused on their awareness of the effects of coastal erosion and the vulnerability of coastal infrastructure in Ghana. Views of key informants on responses to effects of shoreline erosion and the institutional capacity available for adaptation were also sought.
The third part was analysis and interpolations of base maps and topographical sheets of the community and photographs of buildings sited along the shoreline. The base map and topographical sheets were obtained from the Town and Country Planning Department (TCPD) and the Survey Department of Sekondi in the Western Region of Ghana. The base map provided the extent of the shoreline as of July 1976. The topographical sheets gave the extent of the eroded shoreline as at 1991. Interpolations of the base map and topographical sheets were made to establish rates of recession of the shoreline and the extent of land that was lost to the sea. The extent of land lost in conjunction with the building density was used to establish the number of buildings lost. Photographs of affected buildings along the shoreline of Nkontompo were taken and analysed within the context of the research. In view of the fact that there is general lack of data on the coastal topography of Ghana, and specifically for the community to the required scale and accuracy, the researchers had to make intelligent inferences from earlier studies including EPA (2000) .

\section{FINDINGS AND DISCUSSIONS}

The study shows that, as far as shoreline erosion is concerned, the issue at stake required technically engineered approaches and as such it is beyond the capacity of the community. The interview sessions with the members of the community revealed that further erosion of land and their structures are anticipated if the situation is not checked.

The study revealed that there has been occasional displacement of people in the study area, not out of the community but to settle in other parts of the community. At one such instance some 368 people were rendered homeless (Ghanaian Times, 2003). Their houses, shops and other social infrastructure were washed away by tidal waves. According to the estimates made by the authors, approximately 1,168 people have been displaced over the past 26 years. From the information provided by the 


\section{Olympio and Amos-Abanyie}

residents through interviews and careful analysis of the base map obtained from the TCDP, the northern end of the community remained a forest until the last 26 years but has gradually been occupied by people displaced as a result of erosion of their buildings close to the shoreline. According to members of the Community Development Committee (CDC), in the early 1970's, the government put up a residential estate on an elevated part of the community that was found safe to accommodate the affected people in the community. This was on an elevated part of the community that was found safe. This part of the community is now called "Estates" by the residents.

From the interview it was also realized that some residents have migrated out of the community. Such people happen to be those not involved in fishing as a source of livelihood. On the contrary the interview also revealed that some people have moved from elsewhere to settle in the community because cost of living, for instance rent, is found to be relatively lower.

\section{Recession of the shoreline of Nkontompo}

The physical survey conducted at Nkontompo revealed that possible increase in ocean currents have overwhelmed the revetment wall that was constructed in 1990 (Plate 1). This may be attributed to the sandy nature of the shoreline of Nkontompo which does not provide a sound base. The structure has thus given way. A new revetment wall is being constructed at the cross -section of the receded shoreline. According to the experts involved, the new revetment wall is expected to be wider and higher and more bolder rocks are being used.

The key informants interviewed, saw the management of the shorelines of Ghana in the light of projected global rising sea levels as a great challenge. This is because the primary means for managing coastal erosion has been the protection of shorelines with hard-engineered

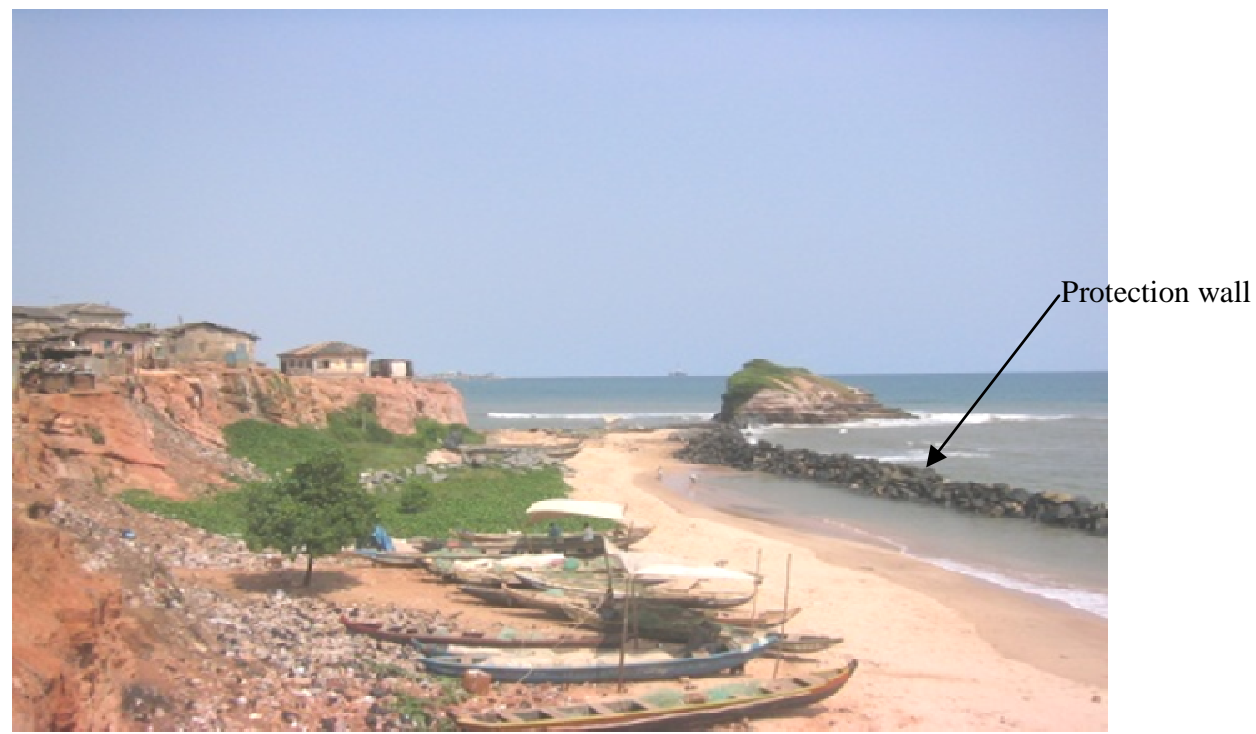

Plate 1: Shoreline has receded beyond the protection wall in place

(Source: Photographs from authors' field survey, Nov. 2009)

Journal of Science and Technology @ KNUST December 2013 
structures.

The sandy nature of the Ghanaian beaches without bedrock to provide a good foundation for the construction of hard-engineered structures has rendered such structures temporary by default. With the case of Nkontompo, either the beach will have to be replenished periodically at great cost or bolder rock will have to be added to maintain the structure with time.

The interpolation made based on the scales of the drawings indicates that between 1979 and 1991 the shoreline had receded by an average distance of 28.3 meters (Plates $2 \mathrm{a} \& \mathrm{~b}$ ). This implies that the shoreline has been receding at approximately 1.89 meters annually. The rate of recession for the period beyond 1991 till November 2003 was also assessed. A revetment wall was constructed over the period from the late 1991 to middle of 1992.

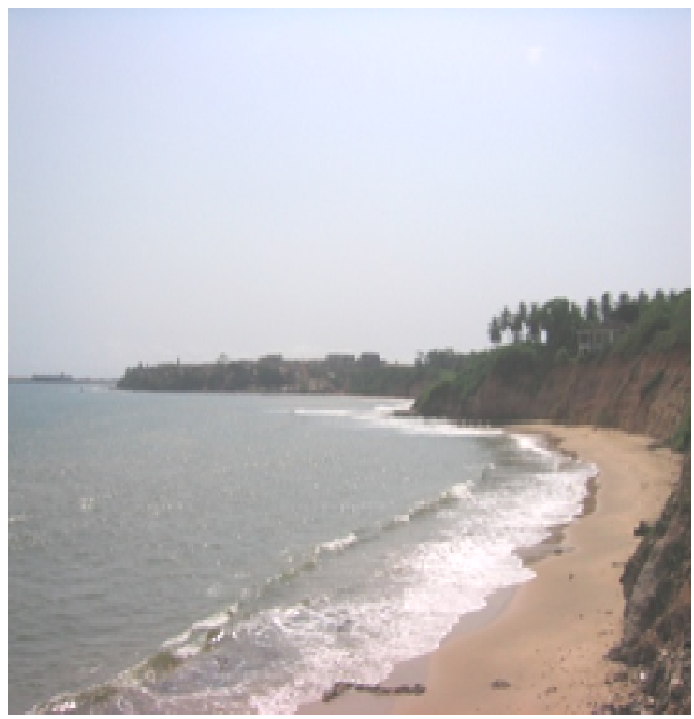

Plate 2a: A large expanse of the community's land is lost as a result erosion

(Source: Photographs from authors' field survey, Nov. 2009)
Further assessments were carried out based on the locations of the revetment wall and that of the existing shoreline. From information gathered in an interview with staff of the technical wing of the then Ministry of Works and Housing, the revetment wall in 1991 was located at the eroding surface of the shoreline. Reports made available to the authors also confirmed that information (Cotsape and Hayes, 1997).

The physical survey revealed that the shoreline had receded to a position of approximately 25.2 $\mathrm{m}$ beyond the defence wall. Over the 12 year period, the rate of recession is approximately $2.1 \mathrm{~m}$ annually. The rates of recession from the two periods suggest an approximate rate of recession of $2 \mathrm{~m}$ per annum. However, the rate was relatively higher in the last decade. The physical survey revealed that the area has sandy and muddy base that easily erodes. The above developments suggest that if no effort is taken

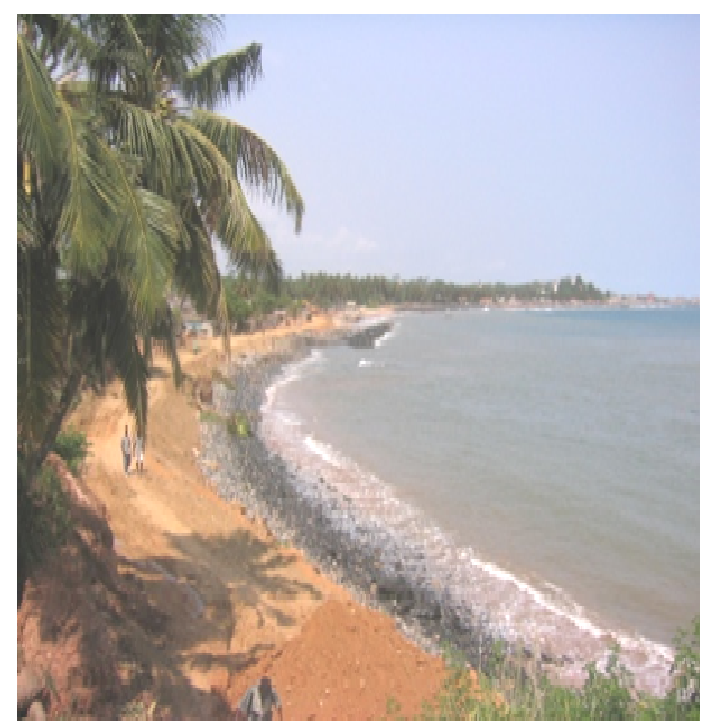

Plate 2b: An eroded street of the community is being reconstructed 
to secure the shoreline and the current recession rate continues, virtually the entire settlement, with a width of approximately $0.407 \mathrm{~km}$ from the shore, could be lost to the sea within the next 200 years. The shoreline recession in Nkontompo is also seen to result from the offshore transport of sand. According to Anthonio (1993) shorelines with substantial amounts of clay and peat could erode faster than sandy ones.

If the average life cycle of a building is taken as 60 years (Ranson, 1995), then with the rate of erosion of $2 \mathrm{~m}$ per year, a setback will have to be set at a minimum distance of $120 \mathrm{~m}$ from the shoreline for all prospective developments in the community. It will also restrict any expansion of existing structures or rebuilding of affected structures seaward of the setback line. A setback will not only protect beachfront structures in the community from erosion and storm waves, but will conserve the natural defences of the shoreline, i.e. sand dunes that would have been bulldozed, cleared, and/or filled, as seen in the case of Keta.

\section{Loss of Land by Erosion at Nkontompo}

The physical survey revealed that a great extent of land is lost. Due to the geomorphology of the Nkontompo shoreline, there has been extensive erosion resulting from physical removal of sediment by wave and current action. The erodible cliffs of the coastline of Nkontompo has promoted the off shore transport of sedimentary material.

According to descriptions given by the elderly people who formed about $65 \%$ of the respondents about a third of the community's land is lost as a result of shoreline-erosion. From the topographical sheet interpolations and analysis made by the authors, it was realized that approximately nine acres of the built environment, forming a third of the total land area had been lost. These compares well with the estimations given by local residents in the descriptive interviews conducted. The end of the protruding segment into the sea indicates the extent of the shoreline about 20 years ago. Plates 3 and 4

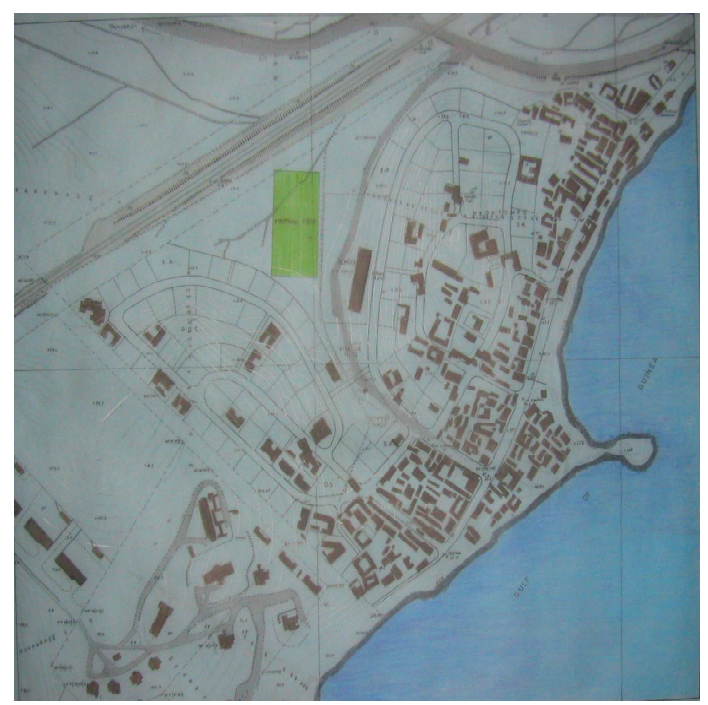

Plate 3: Base map of Nkontompo

(Source: Town and Country Planning Department, Sekondi -Takoradi, 1991)

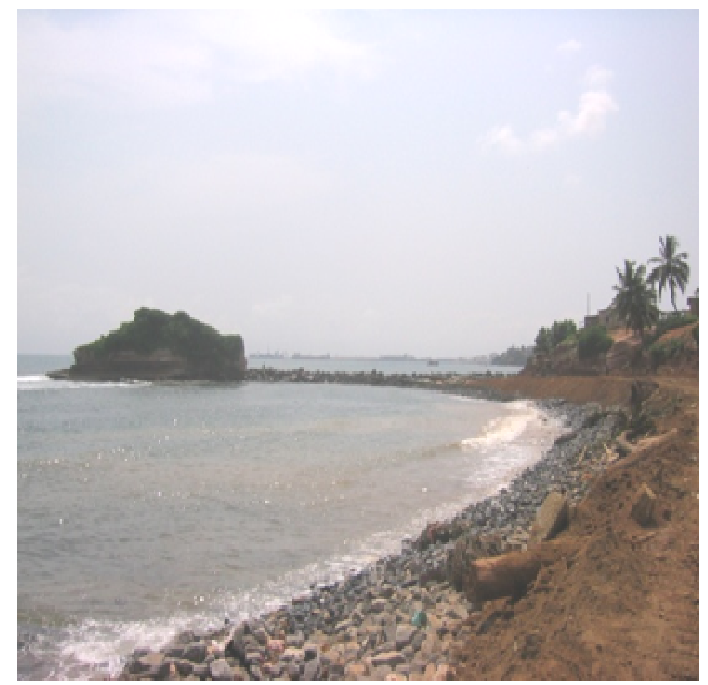

Plate 4: View of the Shoreline of Nkontompo showing the protruding end detached from the mainland

(Source: Photograph from authors' field survey, Nov. 2003) 
demonstrate these. The sides have eroded together with the infrastructure that was on it. These include homes, communal buildings, streets, and drainage systems.

\section{Building Conditions and Number of Build- ings Lost}

The number of buildings lost was estimated based on the area of land lost and the building density of the settlement. The physical survey conducted with the aid of the available base maps gave a building density of the community to be 18 buildings per acre of land. Estimation based on the building density and the area of land lost revealed that approximately 117 buildings have been damaged and subsequently lost to the sea.

About $30 \%$ of the buildings at the beachfront have their foundations exposed, and about $41 \%$ have cracks in wall fabric (Plate 5). This could be as a result of differential settlement resulting from land submergence. Owners of properties

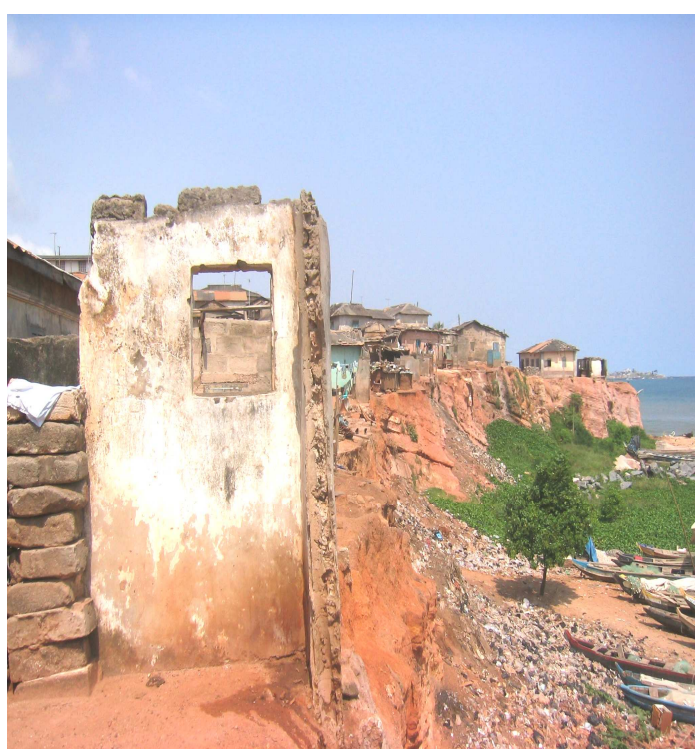

Plate 5: Damaged walls and exposed foundations of buildings

(Source: Photograph from authors' field survey, Nov. 2003) along the shoreline have depreciated their structures to zero value since they anticipate the effects of the erosion.

According to the information obtained from the Community Development Committee, a Community Centre, the Chief's palace, and other related facilities collapsed due to erosion and exposure of their foundations. A major street running through the centre of the town was washed away. Utility service lines including electricity lines and poles, and standpipes were all lost. In case of failure of the new defence wall under construction in some years to come, the existing buildings along the shoreline may be affected. In the light of the danger it posses, consideration will have to be given to relocating the affected buildings further inland, beyond an established setback line.

\section{Flooding}

In spite of the lack of data on the parameters needed for analysis on a flood-frequency probability curve, the interview with the local residents revealed that there has not been an event of flooding along the coast of Nkontompo. That may be attributed to the elevated nature of the settlement with respect to the sea level, three meters to thirty-three meters. Reports from other researchers also revealed that the west of the Central Coast generally does not suffer from flooding (Armah and Amlalo, 1998).

\section{Socio-Economic Effects of protecting the Shorelines of Nkontompo}

The research revealed that the people had no clear information about the ongoing remedial measures of protecting the shoreline. Although the community is happy about the construction of the wall they however raised some concerns about the use of hard protective measures because that limits their access to the beach front. One of the key informants asserted that one dilemma of combating shoreline erosion was the fact that, the number of people owning and occupying beachfront buildings was small relative to the number who would like to use the beach for other purposes such as fishing and 
recreation.

\section{RECOMMENDATIONS}

Based on the findings of the study, it is proposed that a new legislation that will require the establishment of a setback for all developments in the coastal belt is passed, especially along the sandy East and West Coasts. The set back should be determined by the annual rate of recession in these areas. All new development within this line should be required by law to show that, the development in question will be safe from coastal hazards for a period of at least 60 years (Ranson, 1995), which is the average life span of a building.

This setback measure will be most suited for the parts of the Ghanaian coast that are not yet developed. The setback line approach will avoid locating prospective structures close to an eroding beach. Knowledge of historical rates of erosion for particular coastal segment will have to be established. With the assumption that this rate will remain the same in the future, a setback line should be determined where the shoreline position will not reach during the lifetime of the proposed structures within the area.

Setbacks could be applied to the Central Coast. According to the EPA of Ghana, average annual erosion within this segment is often less than 1 metre. The set back of these areas could then be established at 60 metres. Similarly for the general erosion rates of the East and West Coasts, setback of 200 metres and 100 metres respectively should be safe. On the East Coast, erosion of the shores may be occurring at an average rate of $3 \mathrm{~m}$ per year currently (Cotsape and Hayes, 1997). However, more detailed studies will be required to ascertain the recession rates for specific areas. For some of the areas that could be affected, the cost of relocations may be far less than the cost of protection in the long-term. For shores that have been underdeveloped, more detailed analysis should be made to come up with a rational response.
It is also proposed that a coordinating board be created to harmonize all the activities of the coastal districts to ensure that no coastal segment can be treated in isolation. It is recommended that experts in the various fields of coastal management; erosion, flooding, economics, law, planning, technocrats from research institutions should be involved.

\section{CONCLUSION}

The study revealed that environmental conditions at Nkontompo have changed over the past three to four decades as a result of shoreline erosion. The shoreline of Nkontompo has been receding leading to loss of an appreciable number of buildings, roads, service facilities and land to the sea. Other parts of the Ghanaian coastal belt may be having the same experience in a few years from now. It would be prudent to carry out sound research to determine these areas in anticipation and apply appropriate measures to manage the retreat. The hard engineering measures undertaken have proven ineffective. Where relocation becomes necessary, education of the people living along the shoreline will have to start early enough and not when the situation becomes an emergency. The affected communities will have to be educated and motivated by assisting them with resources to rebuild their homes since the cost of protection may be far more than the cost of relocating in the long-term.

\section{REFERENCES}

Al-Tahil and Asim (2004). Assessing land cover changes in the coastal zone using aerial photography. Surveying and Land Information, 64 (2), 107-112

Anquandah, K. J. (1999). Castles and Forts of Ghana. Ghana Museums and Monuments Board and Atalante, Paris

Anthonio, S. L. (1993). "Shoreline erosion along the east cost of Ghana:" in Coastlines of West Africa Coastal Zone, American Society of Civil Engineers, New York, USA 
Anthony, E. J. (2005). Beach Erosion. Encyclopedia of Coastal Science. Ed Schwartz, M.L. Springer Publishers.

Appeaning-Addo, K. (2009). Detection of Coastal Erosion Hotspots in Accra, Ghana, Journal of Sustainable Development in Africa, 11(4), 253-265.

Appeaning-Addo, K., Walkden, M. and Mills, J. P. (2008). Detection, measurement and prediction of shoreline recession in Accra, Ghana. ISPRS Journal of Photogrammetry and Remote Sensing, 63(5), 543-558.

Armah, A. K. (1991). Coastal erosion in Ghana: causes, patterns, research needs and possible solutions. In American Society of Civil Engineers. Coastal Zone '91: Papers read at the Seventh Symposium on Coastal and Ocean Management held in New York. New York, NY: ASCE. 2463-2473.

Armah, A. K. and Amlalo, D. S. (1998). Coastal Zone Profile of Ghana. Accra, Gulf of Guinea Large Marine Ecosystem Project. Ministry of Environment, Science and Technology

Boateng, I. (2006). Shoreline management planning: can it benefit Ghana? A case study of UK SMPs and Their Potential Relevance in Ghana. Promoting Land Administration and Good Governance, 5th FIG Regional Conference, Accra, Ghana, 8-11March, 2006. Available at: https://www.fig.net/pub/accra/ papers/ts16/ ts16_04_boateng.pdf Date of access: August 2012

Campbell, M. O. (2006). The sustainability of coconut palm Cocos Nucifera Linnaeus 1753 in Coastal Ghana. Journal of Coastal Research, 22 (5), 1118-1124.

Cotsapes, L. and Hayes, M. O. (1997). "Environmental Impact Statement for Keta Sea Defence Works Project”, Ministry of Works and Housing, Accra, Ghana.
Crossland, C. J., Kremer, H. H., Lindeboom, H. J., Marshall, J. I. and Le Tissier, M. D. A. (eds. 2005). Coastal Fluxes in the Anthropocene - The Land-Ocean Interactions in the Coastal Zone Project of the International Geosphere-Biosphere Programme. Global Change-the International GeosphereBiosphere Program Series. Springer, Berlin.

EPA (2000). Climate Vulnerability and Adaptation Assessment of Coastal zone of Ghana. Environmental Protection Agency, "The Ghanaian Times" of July 10, 2003.

GSS (2002): “2000 Population and Housing Census", Summary Report of Final Results, Ghana Statistical Service, Accra, Ghana.

Hatziolos, M., Lunden, C. G. and Alm, A. (1996). Africa: A Framework for Integrated Coastal Zone Management. Second edition. The World Bank, Washington, D.C.

IPCC (2001). Technical Summary, Climate Change 2001: Impacts, Adaptation and Vulnerability. Contribution of Working Group II to the Third Assessment Report of the Intergovernmental Panel on Climate Change. Cambridge University Press, New York. http://www.grida.no/climate/ipcc tar/wg2/ pdf/wg2TARtechsum.pdf. Date Assessed: Sept. 2010.

Ly, C. K. (1980). The role of the Akosombo Dam on the Volta River in causing erosion in central and eastern Ghana (West Africa). Marine Geology, 37(3-4), 323-332.

NADMO ( 2007). Hazard Mapping in Ghana. Unpublished report by National Disaster Management Organisation (NADMO) / Government of Ghana.

Nail, G. G., Addo, M. J. A. and WellensMensah, J. (1993). Coastal erosion points in Ghana and their protection. Report of the national workshop on climate climate change and its impact on water, oceans, fisheries and 
coastal zones. Accra: Ghana national committee for the international hydrological programme, pp. 189-202.

Oteng-Ababio, M., Owusu, K. and AppeaningAddo, K. (2011). The vulnerable state of the Ghana coast: The case of Faana-Bortianor. JAMBA: Journal of Disaster Risk Studies, 3 (2), 429-442.

Ranson, W. H. (1995). Building Failures; Diagnosis and Avoidance, 2nd Edition, E and FN Spon, London.

Ricketts, P. J. (1986). National policy and management responses to the hazard of coastal erosion in Britain and the United States. Applied Geography, 6(3), 197-221.
Samli, A. C (2010). Infrastructuring: The Key to Achieving Economic Growth, Productivity, and Quality of Life, Springer Publishers, New York.

TCPD (1991). Base map of Nkontompo. Town and Country Planning Department (TCPD), Sekondi-Takoradi, Ghana.

WCD (2000). Dams and Development - A New Framework for Decision-Making: the Report of the World Commission on Dams. World Commission on Dams. Earth scan Publications Ltd., London. http:// www.dams.org/report/contents.htm. Date Assessed: August 2011. 